\title{
Techno-material and Socio-environmental Model for Assessing Urban Sustainability
}

\author{
Cesar WAGNER, Unitec Institute of Technology, New Zealand
}

\begin{abstract}
The term "sustainable development" first appeared as part of discussions regarding the capacity of natural ecosystems to support the current model of economic growth, assuming a strong concern with the preservation of the planet's environmental structures. Initially, these concerns were conceived on a global scale, but soon the need to bring the discussions to the urban locus the impact of large human agglomerations on the territory and its natural resources - was realized. Thus, the local scale gained importance, since most of the environmental problems originate in the local urban structures and through the lifestyle that they advocate. Cities are serious consumers and degraders of the natural ecosystem, waterproofing soils, polluting the atmosphere, altering the landscape and consuming resources. Based on studies produced by French geographer Cyria Emelianoff and Brazilian economist Henri Acselrad, on the systematization of different representations and practices in urban sustainability, this research paper aims to introduce the design and development of an evaluation model able to assess the degree of sustainability using a techno-material and socio-environmental set of criteria. This model is intended to serve as a benchmark for both the formulation and evaluation of plans, projects and public policies focused on genuine sustainable development.
\end{abstract}

\section{Keywords}

Sustainable development, Urban sustainability, Urban policies, Evaluation model

\section{Introduction}

The term "sustainable development" first appeared as part of discussions regarding the capacity of natural ecosystems to support the current model of economic growth, assuming a strong concern with the preservation of the planet's environmental balance. Initially, these concerns were conceived on a global scale, but soon the need to bring the discussions to the level of the urban locus was realized.

Due to the impact of large human settlements on the land and its natural resources, the local scale gained importance. Cities are serious consumers and degraders of the natural ecosystem, waterproofing soils, polluting the atmosphere, altering the landscape and consuming large amount of resources. Since most of the environmental problems originate in the urban structures, and through the lifestyle that they advocate, Richard Rogers and Philip Gumuchdjian (1997) argue that:

'Nowhere is the implementation of 'sustainability' more potent and more beneficial than in the city. In fact, the benefits to be derived from this approach are potentially so great that environmental sustainability should become the guiding principle of modern urban design.' (p. 5)

With the city as a new parameter, new aspects have to be considered in relation to the conceptual dimensions of sustainable development; aspects closer to the reality of urban daily life and the repercussions of its modus operandi. These include a more critical approach to examining the relationship 
between society and the environment that seeks new practices and operational alternatives in an increasingly urbanized and heterogeneous world. The urban environment is now perceived as a complex system, composed of several interrelated and interdependent subsystems that form part of a larger network of relationships.

It is argued here, therefore, that the path towards sustainable urban development ${ }^{1}$ must be built through a systemic approach; perceiving and considering the different systems that are in synergy, interacting and influencing each other. This aligns with the view of Marin and Cândido (2013) and Zancheti (2002), who state that:

'[...] the urban space must be understood as a complex system formed by elements and functions that are closely related, from the interdependence and the association between the natural and the built environment, through the presence of human activity in the transformation of the natural environment (Canepa 2007) that, added to a set of distinct interests present in the urban space, generate all the complexity that involves the urban context and establishes the bases for the process of development of cities. Thus, any intervention must capture this dynamic of interrelations, since the change in one element can cause changes in the state of the others.' (Marin and Cândido 2013, p. 1) ${ }^{2}$

'The city is a complex and open system, that is, a system with many variables and with a high degree of internal and external interaction in the system, in which the variables are constantly changing. The sustainability of a city will be a process that must deal with the internal and external relations of the system that comprises it.' (Zancheti 2002, p. 82) ${ }^{3}$

It is essential, then, to look at the city through a transversal reading of the various processes that make up the urban structure, questioning its impact within the functioning of a larger system - its immediate surroundings, or the planet as a whole -, as well as perceiving it as a system made up of several subsystems, in a dialectical relationship between local and global issues.

Based on this perspective, several notions of sustainability emerge with the intention of describing situations that present a proximity to reality or that are relevant to the urban system in its various interrelations and contexts. The different appropriations of the notion of urban sustainability generate a diversity of concepts and interpretations, and the city starts to be seen as a fragmented space in its problems, relationships, policies and urban management, generating inconsistent or less satisfactory results.

In the search for for an effective approach to the systematization of the different representations and practices on urban sustainability, two authors stand out in their analysis: the French geographer Cyria Emelianoff (1995) and the Brazilian economist Henri Acselrad (1999). Based on their studies, on the systematization of different representations and practices in urban sustainability, this paper aims to introduce an evaluation model capable of assessing the degree of sustainability using a set of technomaterial and socio-environmental criteria.

\section{Notions of urban sustainability}

In 1995, Cyria Emelianoff (1995) identifies three different representations of sustainable cities, which also correspond to different meanings capable of legitimizing and giving durability to the integrity of the urban. Through the analysis of the International Network of Sustainable Cities, which was formed in Europe, in $1994^{4}$, Emelianoff realizes that these cities act, through transversal actions, on three fronts: i) ecosystem; ii) heritage; and iii) democracy. 
According to Emelianoff, the construction of an ecosystemic city represents a metabolic conception of the city; the search for the equilibrium between materials and flows. Among the strategies involved are: an emphasis on the use of renewable energies and the taxation of non-renewable energy; reducing commuting, by planning areas with mixed functions and local jobs; the rationalization of transport by encouraging pedestrianization, the use of public transport and cycling programs; no subsidy for private cars and the incentive to work from home or distance learning; the decrease in the transportation of goods by the encouragement of an economy of proximity. These cities are mobilizing to prevent the greenhouse effect, against the depletion of the ozone layer and in favour of recycling waste, where the watchword of their action is a healthy living.

In the same analysis, the construction of the heritage city is led by historic or tourist cities that have already identified a natural or cultural heritage. The watchword is quality of life. Its strategies are aimed at the requalification of the urban fabric, public spaces, city blocks and historic buildings; the enhancement of living and natural heritage, including urban fauna and flora; the recovery of streams, rivers, deactivated ports and industrial areas; the valorisation of urban living.

Finally, the participatory city is supported by cities that wish to reconstruct their community identity; their urban dynamics. The watchword is civic life. Among the strategies developed are: the mobilization of residents in relation to urban policies; the development of partnerships; and the construction of formal and informal political participation strategies (see Table 1).

\begin{tabular}{|c|c|c|c|}
\hline $\begin{array}{c}\text { Action } \\
\text { (type of city) }\end{array}$ & Representation & Strategy & Principle \\
\hline Ecosystemic & $\begin{array}{l}\text { - Metabolic } \\
\text { conception; } \\
\text { - Equilibrium } \\
\text { between } \\
\text { materials and } \\
\text { flows. }\end{array}$ & $\begin{array}{l}\text { - An emphasis on use of renewable energies and the } \\
\text { taxation of non-renewable energy; } \\
\text { - reducing commuting by planning areas with mixed } \\
\text { functions and local jobs; } \\
\text { - the rationalization of transport by encouraging } \\
\text { pedestrianization, the use of public transport and } \\
\text { cycling programs; } \\
\text { - no subsidy for private cars and incentive to work from } \\
\text { home or distance learning; } \\
\text { - the decrease in the transportation of goods and the } \\
\text { encouragement of an economy of proximity. }\end{array}$ & $\begin{array}{l}\text { Healthy } \\
\text { living }\end{array}$ \\
\hline Heritage & $\begin{array}{l}\text { - Natural; } \\
\text { - Cultural; } \\
\text { - Historical; } \\
\text { - Touristic. }\end{array}$ & $\begin{array}{l}\text { - the requalification of the urban fabric, public spaces, } \\
\text { city blocks and historic buildings; } \\
\text { - the enhancement of living and natural heritage, } \\
\text { including urban fauna and flora; } \\
\text { - recovery of streams and rivers; } \\
\text { - enhancement of public spaces and urban living. }\end{array}$ & $\begin{array}{c}\text { Quality of } \\
\text { life }\end{array}$ \\
\hline Participatory & $\begin{array}{l}\text { - Community } \\
\text { identity; } \\
\text { - Urban dynamics. }\end{array}$ & $\begin{array}{l}\text { - the mobilization of residents in relation to urban } \\
\text { policies; } \\
\text { - the development of partnerships; } \\
\text { - the construction of formal and informal strategies of } \\
\text { political participation. }\end{array}$ & Civic life \\
\hline
\end{tabular}

Table 1: Classification and characterization of the distinct representations and sustainable practices of cities identified by Cyria Emelianoff (1995).

Acselrad (2004) describes Emelianoff's position on cities that are candidates for "sustainability" as having "a logic of inclusion":

'[...] in a spatial and temporal continuity: inclusion of peripheries (through decentralization), memory (through recovering) and social actors (through interaction) - including non-living and absent generations. Inclusion of the city in the global ecosystem and the local ecosystem in the city; inclusion of the city in the heritage of future generations and local heritage in the cities; inclusion of participatory democracy in the city and the city in "planetary democracy"' (p. 29) 
Following a direction similar to the study produced by Emelianoff (1995), Henri Acselrad (1999) also identifies three proposals for adaptive reproduction of urban structures, aimed at addressing environmental issues in general and urban environmental issues in particular:

'In today's debate we are to find many logical connections between the reproduction of urban structures and their specifically material base. In particular we are to find three basically different representations of the city, to which there are corresponding and likewise different meanings of what is legitimately claimed to be capable of making urban integrity last.' (p. 82$)^{6}$

These representations, or discursive matrices of urban sustainability (Acselrad 1999), manifest themselves through: i) technical-material representation of cities; ii) the city as a space of "quality of life"; and iii) the city as a space for legitimization of urban policies (see Table 2). The "technical-material representation of cities" addresses aspects aimed at the adoption of eco-energetic rationality or urban metabolism mechanisms: in the use of natural resources and in the flow of matter-energy, encompassing less waste of energy and feedstock, as well as recycling and reuse of waste. This matrix is directly related to the new technical models and urban materiality:

'[...] it would fall to urban planning to minimize energetic degradation and slow down the course of irreversibility. Such a representation of the city points to new technical models for the urban founded on economic rationality applied to matter-energy flows.' (Acselrad 2003, p. 5)

Like Emelianoff (Table 1), Acselrad's understanding of this flow includes spatial relationships consumption of space, distribution of people and activities -, since these can increase or reduce energy losses, which would be related to the idea of supporting capacity in urban spaces (Magalhães, 2006). Achieving a more adequate distribution of populations and activities in a given city area would represent an economy of means, preventing great fragmentations and urban dispersions. Acselrad (2003) makes clear that:

'Eco-energetic efficiency can also be translated in terms of spatial distribution that is inadequate to the economy of means, that is, as the result of an improper locational distribution of population and activities within the urban space.' (p. 6)

In this regard, Durazo (1997 as cited by Acselrad 2009, p. 55) argues that unsustainability would thus derive from the "[...] increasing asymmetries between the spatial location of resources and the population, from the excessive pressures on the surrounding environment and on the regional ecological systems.". In material and physical terms, cities must be understood as structures that demand energy, materials from other places and still need areas for the disposal of their waste, which grows every day with the encouragement of consumption and the durability of goods increasingly shorter. With population growth, cities tend to spread out, consuming important natural ecosystems and arable land.

The transition (or evolution) to urban technical-based projects should be supported by a change in habits; an environmental re-education, through the dissemination of an ecological conscience and "[...] by the engendering of a "recycling economy"'" (Acselrad 2003, p. 6). Acselrad argues that the search for an urban ecological balance, based on the ecosystemic representation of the city, should be guided by a circular metabolism, "the idea of urban metabolism [...]" (Ibid., p. 7), where consumption is reduced, processes are more efficient and resource reuse is maximized: "The idea of urban metabolism refers to a model of equilibrium to be obtained through proper adjustment of the flows and stocks of matter and energy." (Ibid.). Materials must be recycled, waste reduced, non-renewable resources conserved and the consumption of renewables must be insisted upon.

These processes increase the global efficiency of cities and reduce their impact on the environment. For this, cities must be planned to manage the use of resources and waste disposal, reducing their ecological 
footprint, through a new vision of more systemic and comprehensive planning. In this respect, a sustainable city:

'[...] will be the one that, for the same service offer, minimizes the consumption of fossil energy and other material resources, making the most of local flows and satisfying the criterion of conserving stocks and reducing the volume of waste.' (Deléage 1995 as cited by Acselrad 2009, p. $54)^{8}$

In the second representation of the city as space of "quality of life", identified by Acselrad, the focus is given to purity, citizenship, and heritage. It relates to the health implications of urban production and practices, considering that the urban environment "[...] would expose the inhabitants of cities to harmful and toxic substances due to their artificiality." (Acselrad 2009, p. 59). Actions relating to this focus would favour the asceticism and the purity of the city, questioning:

'[...] emissions of gases and other pollutants, seeking their control and reduction through dialogue and negotiation, even if in opposition to industrial development, in an expansion of the notion of citizenship.' (Magalhães 2006, p. 13) ${ }^{9}$

Regarding the practice of citizenship, this refers to the development of instruments for dialogue and negotiation on public policies:

'Such representation of urban citizenship tends to spread to the set of urban policies, justifying structures that favour the development of dialogue and negotiation, as well as the realization of pacts that give meaning to the duration of cities, not only in their materiality, but as a sociopolitical institutionality.' (Acselrad 2009, p. 60) ${ }^{10}$

Heritage relates to the values, culture, interpretations and perceptions of space over time and the symbolic existence of places. These characteristics are strongly representative of the identity of the place, and strengthen the inhabitants' bond with the place. This notion refers not only to the materiality of cities, but also to their character, their identities, their values and their inheritances built over time:

'The prospect of making the symbolic existence of built sites or signified natural sites last, eventually become "naturalized", can be inscribed both in strategies to strengthen the inhabitants' sense of belonging to their cities, as well as to promote an image that marks the city for its heritage [...].' (Ibid., p. 60) ${ }^{11}$

When these three points - purity, citizenship and heritage - are combined and associated with the concept of sustainability, an interesting picture is built. The quality of life and citizens' rights are processed not only by the simple right to urban space, including all diversity and functionality, but incorporate community participation in the sense of the polis, to effectively exercise citizenship and governance, and to manage their values. In this sense, heritage is also experienced and interpreted, according to individual and collective values that are related to a temporal and spatial reality. Thus, the preservation of the biophysical, aesthetic and cultural heritage of the city would contribute both to strengthening the sense of permanence of its inhabitants and to promote its "ecological" image, attracting investments within the framework of global competition ${ }^{12}$ (Magalhães, 2006).

Finally, the third representation characterized by Acselrad is that related to the notion of "the city as a space for legitimization of urban policies", which would be based on the conditions to legitimize and establish urban policies according to an efficiency and equity model. It would constitute the construction of greater social equity, the distribution of democratic services and practices to the entire population, and administrative efficiency, promoting the appropriate distribution of resources in accordance with social priorities and demands. For Martins and Cândido (2013): 
'This representation of the city can be expressed by the efficiency model through the management of public resources, and by the equity shown by the willingness to democratize access to urban services, demonstrating the capacity of urban policies to adapt the offer of urban services to the quantity and quality of society's demands to promote a balance between supply and demand.' (p. 5) ${ }^{13}$

Magalhães (2006) argues that the erosion of the legitimacy of urban policies has an impact both on the waste of resources and spatially, in the form of socio-territorial segregation as a result of the selective concentration of urban benefits. As a consequence:

'[...] unsustainability, which would increase "the degrees of conflict and uncertainty in the reproduction processes of urban structures", would come from the inability of those responsible for urban policies to provide basic services to all, to prevent the decay of some of their physicaleconomic spaces, and to face technological and natural risks, imposing more risks and inequality on less assisted populations.' (p. 13) 14

\begin{tabular}{|c|c|c|}
\hline Matrix & Model & Strategy \\
\hline $\begin{array}{l}\text { The city in its } \\
\text { technical- } \\
\text { material } \\
\text { representation }\end{array}$ & $\begin{array}{l}\text { - Eco-energy rationality; } \\
\text { - Metabolic equilibrium } \\
\text { (urban metabolism). }\end{array}$ & $\begin{array}{l}\text { - reduced consumption and less waste of energy and } \\
\text { feedstock; } \\
\text { - better distribution of populations, uses and activities within } \\
\text { the territory; } \\
\text { - waste reduction and recycling (recycling economy); } \\
\text { - environmental re-education, through the spread of } \\
\text { ecological awareness. }\end{array}$ \\
\hline $\begin{array}{c}\text { The city as a } \\
\text { space of quality } \\
\text { of life }\end{array}$ & $\begin{array}{l}\text { - Purity; } \\
\text { - Citizenship; } \\
\text { - Heritage. }\end{array}$ & $\begin{array}{l}\text { - reduction and control over emissions of gases and other } \\
\text { pollutants; } \\
\text { - develop, together with the community, instruments for } \\
\text { dialogue and negotiation on public policies; } \\
\text { - preservation and promotion of the city's biophysical, } \\
\text { aesthetic and cultural heritage. }\end{array}$ \\
\hline $\begin{array}{l}\text { The city as a } \\
\text { space for } \\
\text { legitimization of } \\
\text { urban policies }\end{array}$ & $\begin{array}{l}\text { - Efficiency; } \\
\text { - Equity. }\end{array}$ & $\begin{array}{l}\text { promote efficiency in the administration of public } \\
\text { resources; } \\
\text { - promote social equity through democratization in the } \\
\text { allocation of public resources. }\end{array}$ \\
\hline
\end{tabular}

Table 2: Classification and characterization of the distinct representations and sustainable practices of cities identified by Henri Acselrad (1999).

\section{Research methodology and analysis}

In reviewing the representations and sustainable practices of cities identified by Emelianoff and Acselrad (Tables 1 and 2), we perceive a strong similarity in the construction of their models, through their organization in three different matrices and their specific dimensions of action.

It seems that such an approach highlights the existence of two specific fields of action to achieve urban sustainability: one with a techno-material basis manifesting itself through the ecosystemic modernization of the city, and another with a socio-environmental basis, translated into the search for socio-environmental justice in city (Table 3). The first field, based on the premises of not wasting and not polluting, would include the dimensions of an expanded technical matrix, in the search for solutions based on a technical process ${ }^{15}$. These are: i) ecoenergetic rationality; ii) metabolic equilibrium; and iii) ecosystemic purity. In the second field, the materiality of the city is seen as politically constructed, where its sustainability is understood by the combination of principles of justice and ecology, suggesting that environmental degradation and social injustices have the same bases and must be analysed together. It is necessary, in order to achieve quality of life, well-being and culture, to discuss a new ethics of sustainable development, with participation, political responsibility and social justice. The dimensions represented 
here are: iv) citizen participation; v) integral heritage; vi) administrative efficiency; and vii) socioterritorial equity. Thus, the duration of the city (Acselrad 2009), and consequently the reproduction of its social relations, would be ensured not only in its materiality, but mainly as a space of legitimization and citizen participation.

\begin{tabular}{|c|}
\hline $\begin{array}{l}\text { Techno-material basis } \\
\text { (The ecosystemic modernization of the city) }\end{array}$ \\
\hline $\begin{array}{l}\text { Description: adaptive reproduction of urban structures to adjust the city's technical and sanitary bases, with } \\
\text { regard to ecoenergetic rationality, metabolic equilibrium and the purity of the system, aiming at reducing both } \\
\text { the use of resources and the production of waste, as well as emissions gases and other pollutants, through the } \\
\text { search for a better distribution of the population and activities in the urban space. } \\
\text { Criterion: a city will have better material continuity of stocks and flows of resources and waste, as well as healthy } \\
\text { conditions of existence, the more appropriate its practices are in search of ecoenergetic rationality, metabolic } \\
\text { equilibrium and ecosystemic purity. }\end{array}$ \\
\hline $\begin{array}{l}\text { Dimension 1: Ecoenergetic rationality } \\
\text { Dimension 2: Metabolic equilibrium } \\
\text { Dimension 3: Ecosystemic purity }\end{array}$ \\
\hline $\begin{array}{l}\text { Socio-environmental basis } \\
\text { (Social and environmental justice in the city) }\end{array}$ \\
\hline $\begin{array}{l}\text { Description: it is related to the socio-environmental, cultural and institutional components of urban practices, } \\
\text { with regard to the full conditions of citizen participation in discussions and social pacts, in the preservation of the } \\
\text { city's integral heritage, and in the reconstitution of the legitimacy of urban policies to adapt the infra-structure } \\
\text { and services to the demands of the entire population. } \\
\text { Criterion: a better city will promote socio-environmental justice, the more appropriate are the ways to promote } \\
\text { citizen participation, local integral heritage, and the adaptation of urban service offerings to the quantity and } \\
\text { quality of social demands through the legitimacy of urban policies in the ensuring administrative efficiency and } \\
\text { socio-territorial equity for the entire population. }\end{array}$ \\
\hline $\begin{array}{l}\text { Dimension 4: Citizen participation } \\
\text { Dimension 5: Integral heritage } \\
\text { Dimension 6: Administrative efficiency } \\
\text { Dimension 7: Socio-territorial equity }\end{array}$ \\
\hline
\end{tabular}

Table 3: Bases and dimensions of urban sustainability.

That said, this paper proposes the construction of a conceptual model (Table 4), structured on these two bases - a techno-material and a socio-environmental one - as an ordering framework for the analysis and verification of sustainability in the city. This conceptual model presents, for each of its 3 techno-material and 4 socio-environmental dimensions, the description and criteria for the analysis of urban sustainability. It proposes to serve as a parameter both for the formulation and for the evaluation of plans, projects and public policies aimed at sustainable urban development.

\begin{tabular}{|c|c|}
\hline & $\begin{array}{l}\text { Techno-material basis } \\
\text { (The ecosystemic modernization of the city) }\end{array}$ \\
\hline Dimension 1: & \multirow{3}{*}{$\begin{array}{l}\text { Description: conservation of matter and energy, with reduction of environmental } \\
\text { externalities in the process of extraction, treatment, consumption and discharge; adequate } \\
\text { spatial distribution of these resources in relation to populations and activities in the urban } \\
\text { space, privileging local resources. } \\
\text { Criterion: in material terms: a city presents eco-energetic rationality when, for the same offer } \\
\text { of services, it manages to minimize the consumption of energy and other material resources, } \\
\text { making the most of local flows, conserving stock and reducing the production of waste. In } \\
\text { terms of spatial distribution: a city has eco-energetic rationality, the better the spatial } \\
\text { distribution of the technical pressure of populations and activities on the basis of urban } \\
\text { environmental resources. }\end{array}$} \\
\hline & \\
\hline $\begin{array}{c}\text { Ecoenergetic } \\
\text { rationality }\end{array}$ & \\
\hline Dime & \multirow{2}{*}{$\begin{array}{l}\text { Description: seeks to adjust the flows and stocks of matter and energy to achieve } \\
\text { equilibrium, based on the adaptive capacity of urban ecosystems (resilience) to overcome } \\
\text { vulnerable conditions and external threats. }\end{array}$} \\
\hline & \\
\hline
\end{tabular}




\begin{tabular}{|c|c|}
\hline & \\
\hline & \multirow{2}{*}{$\begin{array}{l}\text { Description: aspects evoked to question the technical bases of the urban, which due to their } \\
\text { artificiality could expose the urban population to harmful and toxic substances. } \\
\text { Criterion: a city will present healthy conditions of existence the more it knows the } \\
\text { consequences of urban practices and technologies, questioning and reducing the health } \\
\text { implications of such practices. }\end{array}$} \\
\hline & \\
\hline \multicolumn{2}{|r|}{$\begin{array}{l}\text { Socio-environmental basis } \\
\text { (Social and environmental justice in the city) }\end{array}$} \\
\hline & \multirow[b]{2}{*}{$\begin{array}{l}\text { Description: related to the existence of structures in the urban space that favour dialogue, } \\
\text { negotiation, and citizen participation, aiming at making pacts to give meaning to the duration } \\
\text { of cities. } \\
\text { Criterion: a city will be better assured of the right to citizen participation the better it } \\
\text { promotes dialogue, negotiation and the execution of pacts that result in the } \\
\text { institutionalization of collective representation. }\end{array}$} \\
\hline & \\
\hline & \multirow{3}{*}{$\begin{array}{l}\text { Description: material and immaterial aspects (character, identity, values and inheritances) } \\
\text { built throughout the history of the city, which make the symbolic existence of the natural and } \\
\text { built heritage last, expressed through the historical, cultural and environmental aspects, } \\
\text { which strengthen the roots and the origins of its people through the conservation of local } \\
\text { identities. } \\
\text { Criterion: a city will better preserve its integral heritage, the better it preserves its historical, } \\
\text { cultural and environmental aspects that have been and are part of its history throughout its } \\
\text { existence. }\end{array}$} \\
\hline & \\
\hline & \\
\hline & \multirow{2}{*}{$\begin{array}{l}\text { Description: adequate and efficient management of public resources to meet the demands o } \\
\text { society, through the political and institutional capacity to intervene in the urban structure. } \\
\text { Criterion: a city will have a better administrative efficiency in the management of public } \\
\text { resources, the better the ways it has of developing its political and institutional capacity in } \\
\text { promoting and distributing these resources according to local priorities. }\end{array}$} \\
\hline & \\
\hline & \multirow{2}{*}{$\begin{array}{l}\text { Description: urban conditions and equitable distribution for the access of services to the } \\
\text { entire population. } \\
\text { Criterion: a city will have better socio-territorial equity in the distribution of services (quality } \\
\text { and quantity), to the entire population, when its public policies to democratize access to } \\
\text { urban services are most appropriate. }\end{array}$} \\
\hline & \\
\hline
\end{tabular}

Table 4: Techno-material and socio-environmental model for assessing urban sustainability. ${ }^{16}$

Thus, from this conceptual model, an operational model is proposed (Table 5), outlining a total of eighteen specific criteria corresponding to the seven techno-material and socio-environmental dimensions:

\begin{tabular}{|c|c|c|}
\hline Base & Dimension & Specific Criteria (based on action and promotion) \\
\hline \multirow{9}{*}{ 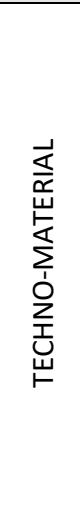 } & \multirow{2}{*}{$\begin{array}{l}\text { Ecoenergetic } \\
\text { rationality }\end{array}$} & $\begin{array}{l}\text { 1. Reduction in the consumption of non-renewable resources, by promoting the } \\
\text { use of renewable energy. }\end{array}$ \\
\hline & & 2. Recycling and reuse of residues. \\
\hline & \multirow{3}{*}{$\begin{array}{l}\text { Metabolic } \\
\text { equilibrium }\end{array}$} & 3. Local resource in energy generation and residue treatment. \\
\hline & & $\begin{array}{l}\text { 4. Adequate distribution of the population and activities in the territory- } \\
\text { promotion of an economy of proximity. }\end{array}$ \\
\hline & & 5. Adaptive and resilient capacity to overcome conditions of vulnerability. \\
\hline & \multirow{4}{*}{$\begin{array}{l}\text { Ecosystemic } \\
\text { purity }\end{array}$} & 6. Waste treatment. \\
\hline & & $\begin{array}{l}\text { 7. Measurement, control, and restriction systems for emissions of gases and other } \\
\text { pollutants. }\end{array}$ \\
\hline & & 8. Promotion of pedestrianization, cycling programs and public transportation. \\
\hline & & 9. Restriction on the use of private cars. \\
\hline
\end{tabular}




\begin{tabular}{|c|c|c|}
\hline \multirow{9}{*}{ 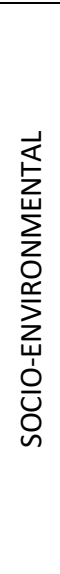 } & \multirow{2}{*}{$\begin{array}{l}\text { Citizen } \\
\text { participation }\end{array}$} & $\begin{array}{l}\text { 10. Construction of formal and informal strategies for dialogue, negotiation and } \\
\text { political participation. }\end{array}$ \\
\hline & & 11. Promotion of social inclusion. \\
\hline & \multirow{3}{*}{$\begin{array}{l}\text { Integral } \\
\text { heritage }\end{array}$} & 12. Preservation and promotion of the built historical heritage. \\
\hline & & 13. Preservation and enhancement of living and natural heritage. \\
\hline & & $\begin{array}{l}\text { 14. Preservation and enhancement of culture, character, sense of belonging and } \\
\text { local identity. }\end{array}$ \\
\hline & \multirow{2}{*}{$\begin{array}{l}\text { Administrative } \\
\text { efficiency }\end{array}$} & 15. Promotion of efficiency in the administration of public resources. \\
\hline & & 16. Promote the distribution of these resources according to local priorities. \\
\hline & \multirow{2}{*}{$\begin{array}{l}\text { Socio-territorial } \\
\text { equity }\end{array}$} & $\begin{array}{l}\text { 17. Promotion of social equity through democratization in the allocation of public } \\
\text { services. }\end{array}$ \\
\hline & & $\begin{array}{l}\text { 18. Promotion and enhancement of public spaces and urban coexistence close to } \\
\text { the entire territory. }\end{array}$ \\
\hline
\end{tabular}

Table 5: Specific criteria for assessing the dimensions of urban sustainability in the techno-material and socio-environmental model.

\section{Conclusion}

There remains a state of uncertainty regarding the concept of sustainability, the construction of its meaning and its consequent application. This is in part due to the time-related issue of a present action influencing a state of future sustainability - something that can only be tested and verified in the future as well as the variety of dimensions associated with the concept: social, environmental, economic, cultural and institutional - and the speed with which social and spatial changes transform cities.

This article does not intend to provide a definitive and final model for assessing the dimensions of urban sustainability. It proposes a model in the making, which should be tested and refined through time. The model is based on the understanding that the search for the construction of sustainability must include consideration of issues from technical matters of urban infrastructure, scale and efficiency, to intangible, transversal and multidimensional issues that permeate the entire physical network of the city, as well as aspects aimed at strengthening citizenship, governance, ethics, culture and social justice (Wagner 2019). Centring on two specific fields of action - the ecosystemic modernization of the city, and socioenvironmental justice in city - along with associated dimensions and criteria for the analysis of urban sustainability, the model is proposed to serve as a parameter both for the formulation and for the evaluation of plans, projects and public policies aimed at sustainable urban development.

It is argued that the application of this conceptual and operational model - which may be imperfect in its nature, but is justified in its principles and its proposition - is valuable not only as a way of monitoring and assessing sustainability in the existing city, but also as an instrument of investigation and analysis of future governmental plans and policies of intervention in urban areas.

\section{Notes}

\footnotetext{
${ }^{1}$ In the context of this work, we will use the term "sustainable urban development" when referring to the process by which "urban sustainability" can be achieved, thus characterizing the "sustainable city".

2 Author's translation of the original in Portuguese.

${ }^{3}$ Author's translation of the original in Portuguese.

${ }^{4}$ Founded in 1994, the International Network of Sustainable Cities was formed from the First European Conference on Sustainable Cities and Towns, held in May of the same year in the city of Aalborg, Denmark, with the objective of starting the process of implementing the Local Agenda 21.
}

${ }^{5}$ Author's translation of the original in Portuguese. 
${ }^{6}$ Author's translation of the original in Portuguese.

${ }^{7}$ Author's translation of the original in Portuguese.

${ }^{8}$ Author's translation of the original in Portuguese.

${ }^{9}$ Author's translation of the original in Portuguese.

${ }^{10}$ Author's translation of the original in Portuguese.

${ }^{11}$ Author's translation of the original in Portuguese.

12 100\% Pure New Zealand, is the brand of New Zealand's official tourism website.

${ }^{13}$ Author's translation of the original in Portuguese.

${ }^{14}$ Author's translation of the original in Portuguese.

15 Acselrad identifies, in his matrix "The city in its technical-material representation" (Table 2), two models, or dimensions: Eco-energy rationality, and Metabolic equilibrium (or Urban metabolism). Here, we propose to expand the dimensions of the techno-material base to three, including an Ecosystemic purity dimension, as we understand that the search for the purity of the system, through the reduction and control of emissions of polluting gases and harmful and toxic substances, can also be found in the use of solutions based on a technical-scientific process.

16 In 2013, Martins and Cândido proposed a model of analysis of urban sustainability based on the 3 discursive matrices identified by Acselrad, containing description, analysis criteria, thematic indexes and urban indicators attributed to each of the 7 dimensions. For the construction of the model presented here, we base our set of descriptions and analysis criteria on both the writings of Emelianoff (1995) and Acselrad (1999), and the discussions proposed by Martins and Cândido (2013). 


\section{References}

Acselrad, H. (1999) 'Discursos da sustentabilidade urbana', Revista de Estudos Urbanos e Regionais ANPUR, n.1, 79-90.

Acselrad, H. (2003) 'The multiple discourses on urban sustainability', Socioeconomic Data and Application Center, Columbia University, viewed 21 August 2020 $<$ http://sedac.ciesin.columbia.edu/openmeeting/downloads/1009003000_presentation_acselrad 1.doc>.

Acselrad, H. (2004) 'Desregulamentação, contradições espaciais e sustentabilidade urbana' Revista Paranaense de Desenvolvimento, n.107, 25-38.

Acselrad, H. (2009) 'Sentidos da sustentabilidade urbana' in Acselrad, H. (ed.) A duração das cidades: sustentabilidade e risco nas políticas urbanas. Rio de Janeiro: Lamparina, pp. 43-70.

Emelianoff, C. (1995) 'Les villes durables: l'émergence de nouvelles temporalités dans de vieux espaces urbains', Ecologie Politique, n.13, 37-58.

Emelianoff, C. and Theys, J. (2000) 'Les Contradictions de La Ville Durable' in Développment Durable Villes et Territoires, no 13, jan., 53-63.

Jenks, M. (2000) 'Introduction: Sustainable Urban Form in Developing Countries?' in Jenks, M. and Burgess, R. (eds.) Compact Cities: Sustainable Urban Forms for Developing Countries. London: Spon Press, pp. 1-6.

Maclaren, V.W. (2004) 'Urban Sustainability Reporting' in Wheeler, S. and Beatley, T. (eds.) The sustainable urban development reader. London: Routledge, pp. 203-210.

Magalhães, R.A.M. (2006) 'A construção da sustentabilidade urbana: obstáculos e perspectivas', III Encontro da ANPPAS. 23-26 May. Brasília, 1-18.

Martins, M.F. and Cândido, G.A. (2013) 'Análise da sustentabilidade urbana no contexto das cidades: proposição de critérios e indicadores', XXXVII Encontro da ANPAD. 7-10 September. São Paulo, 116.

Newman P. and Kenworthy, J. (1999) Sustainability and cities: overcoming automobile dependence. Washington: Island Press.

Pugh, C. (ed.) (1996) Sustainability, the Environment and Urbanization. London: Routledge.

Roger, R. and Gumuchdjian, P. (1997) Cities for a small planet. London: Faber and Faber.

Roseland, M. (1992) Toward sustainable communities: a resource book for municipal and local governments. Ottawa: NRTEE-TRNEE.

Sachs, I. (1992) Transitions Strategies Towards the 21st Century. New Delhi: Nature and Resources.

Wagner, C. (2019) A questão da sustentabilidade nas políticas de desenvolvimento urbano: a reestruturação urbana do baixo $4^{\circ}$ Distrito de Porto Alegre (1995-2016), PhD thesis, Universidade Federal do Rio Grande do Sul, Porto Alegre, viewed 16 August 2020, <http://hdl.handle.net/10183/212145>.

Zancheti, S.M. (2002) 'O desenvolvimento sustentável urbano' in: Zancheti, S.M. (ed.) Gestão do Patrimônio Cultural Integrado. Recife: Editora Universitária da UFPE - Centro de Conservação Integrada Urbana e Territorial, Pós-graduação em Desenvolvimento Urbano, pp. 79-83. 